\title{
PLC-HMI BASED SIMULATION of PV CELL and
}

\section{ARRAY BEHAVIOR}

\author{
Maytham Ali Fadhil \\ Electrical Engineering Department \\ Basrah University \\ Basrah/ Iraq. \\ Eng.maitham_ali@yahoo.com
}

\author{
Jawad Radhi Mahmood \\ Electrical Engineering Departmen \\ Basrah University \\ Basrah/ Iraq. \\ Jawdradhi59@gmail.com
}

\begin{abstract}
This paper presents the PLC-HMI based simulation of electrical-based PV cell/array model in laboratory platform to give the opportunity to students and users who haven't clear knowledge to study PV cell and array behavior with respect to change of environment conditions and electrical parameters. This simulation process covers the cell models under ideal and non-ideal ones. In non-ideal one, the series resistance and the shunt resistance are covered.
\end{abstract}

Index Terms - PLC, HMI, Modelling, Simulation, PV Model

\section{INTRODUCTION}

To efficiently use any item or device, the device specification and behavior under different conditions should be well studied. The lake of knowledge may lead to inefficient use of the device under consideration or damage the device. So, to encourage the people to go ahead with using the PV energy, the PV cell (the basic building block) should be well understood, i.e. its behavior under different environmental conditions should be clear to the user and developer. To go ahead with what has mentioned before, large number of researchers around the world discussed different areas in this context [1].

Huan L.Tsai, et.al.(2008) [2]presented the implementation of PV cell model using Matlab/Simulink to study and analyze the PV cell/module behavior under the effect of irradiation and temperature changes.

Armando Bellini, et.al. (2009) [3] proposed an improved PV module model using the parameters provided by manufactures datasheet.

Snehamoy Dhar, et.al. (2012) [4]presented a circuit-based simulation model to estimate the practical PV cell behavior and simulated process using Matlab/Simulink environment.
Jangwoo Park, et.al. (2014) [5] presented a simple method for mathematical modelling and simulation for the PV panel and applied this model under the Matlab/Simulink environment.

H.Yatimi, et.al. (2015) [6] presented the PV module modelling and simulation under the Matlab environment by taking into consideration the measurements under real working conditions.

M.Diaw, et.al (2016) [7] developed the PV module model for plotting the PV characteristics curves and validate the model by comparing the result with experimental curves.

As it is clear from the above scripts the PV topics have been treated in different ways, but none of them discussed the utilized of the widely used industrial controller, the programmable logic controller (PLC) and the human machine interface (HMI). PLC is a special type of computer. It can work well under harsh environments (high temperature, high humidity, and vibration). The PLC executes the user program downloaded to the PLC's memory. It differs from the hardware circuit implementation by allowing control circuit modification without changing any real wiring because the control approach depends on software instruction rather than hardwiring approach. The PLC can receive command through its digital input 
terminal and its communication ports. The input terminals are only controlled by applying an on/off switching signal. To deal with the whole memory of the PLC a PC or an HMI panel should be used. The HMI is widely used in the industrial field because of its capability to withstand high temperature, high humidity, and vibration. The HMI allows the user to update and monitor the PLC user memory data.

The aim of the current work is to develop PLCHMI simulation utility for the PV module.

\section{PHOTOVOLTAIC CELL MODEL}

In the related literature, the mathematical model has been introduced to the PV cell, there are the single diode model and two diode model. The single diode model has been adopted in this work. To deal with this model for the ideal and non-ideal cases the flowing can be take

- Create an ideal one, Rs value is replaced by zero and neglect the Rp resistance.

- Create non-ideal one, for Rs model neglecting the $\mathrm{Rp}$ resistance and for $\mathrm{Rp}$ model take Rs and Rp in consideration. The single diode model is shown in Fig.1

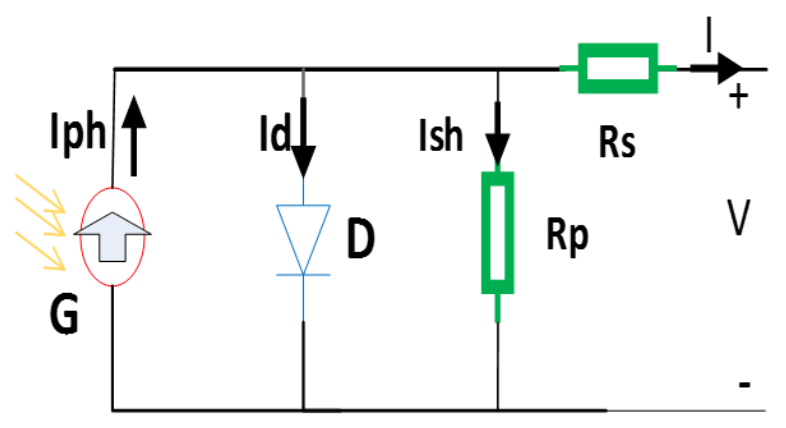

Fig. 1 Single Diode Model of PV Cell

The main equations describing the model are [812]:

$V T=N s K T / q$.

Ion $=I s c n /\left(\exp \left(\frac{V o c n}{A V T n}\right)-1\right)$.

$I o=\operatorname{Ion}\left(\frac{T}{T n}\right)^{3} \exp \left[\left(\frac{q E g}{A K}\right)\left(\frac{1}{T n}-\frac{1}{T}\right)\right]$.

$V o c=V o c n+K v(T-T n)+A V T \ln \left(\frac{G}{G n}\right)$.

Iphn $=\left(\frac{R p+R s}{R P}\right)$ Iscn .

$I p h=(I p h n+K i(T-T n))\left(\frac{G}{G n}\right)$.

$$
I=N p I p h-N p I o\left[\exp \left(\frac{V+I R s}{V T A}\right)-1\right]-\left(\frac{V+I R s}{R p}\right) .
$$

$\left.R p \min =\left(\frac{V m p}{I s c n-I m p}\right)\right)-((V o c n-V m p) / I m p)$.

$R \operatorname{smax}=\frac{A V \operatorname{Tn} \ln \left(\left(\frac{\operatorname{Iphn-Imp}}{\operatorname{Ion}}+1\right)\right)-V m p}{\operatorname{Imp}}$.

$F F=\frac{P m p}{V o c I s c}$.

Where

$V T$ : Thermal voltage at ambient temperature (V) $V T n$ : Thermal voltage at STC temperature (V)

STC: Standard test condition

$T$ : Photovoltaic cell temperature (C)

$T n$ : Photovoltaic cell temperature at STC (C)

$K$ : Boltzmann constant $1.3806503 \mathrm{E}-23 \mathrm{~J} / \mathrm{K}$

$K i$ : Current temperature coefficient $(\% / \mathrm{C})$

$K v$ : Voltage temperature coefficient $(\% / \mathrm{C})$

$F F$ : Fill factor.

$q$ : Electron charge 1.60217646E-19C

Eg: Band energy of the semiconductor $(\mathrm{eV})$

$A$ : Diode ideality constant

$N s$ : Serially connected cells

$N p$ : Parallel connected cells

$R s$ : Series Resistance $(\Omega)$

$R p$ : Shunt resistance $(\Omega)$

Rsmax: Maximum calculated series resistance $(\Omega)$

Rpmin: Minimum calculated shunt resistance $(\Omega)$

Ion: Saturation current at STC (A)

Io: Saturation current (A)

Iscn: Short circuit current at STC (A)

Isc: Short circuit current (A)

Vocn: The open voltage at STC (V)

Voc: Open voltage (V)

$V m p$ : Maximum power point voltage at STC(V)

Iphn: Photocurrent at STC (A)

Iph: Photocurrent (A)

Imp: Maximum power point current at STC (A)

Pmp: Maximum power point power (W)

\section{THE PROPOSED PLATFORM}

The proposed platform shown in Fig. 2 has been arranged and designed to support

- Simulation of PV cell/module modelling.

- Simulation of widely used of maximum power point tracking techniques 
- Real-time PV module curves plotting utilities.

- Real-time implementation of some maximum power point tracking algorithms

The proposed platform consists of XECDR28UA/DC PLC and XP-30TTA/DC HMI to implement the simulation activities. The other components are seen in Fig. 2 related to realtime activities. The model simulation task has been implemented in two parts. These are the PLC related one which is responsible for processing and solving mathematical equations and the HMI related one which has been designed to enable student or user to input and modified the parameters and view the results as values or plotting different curves.

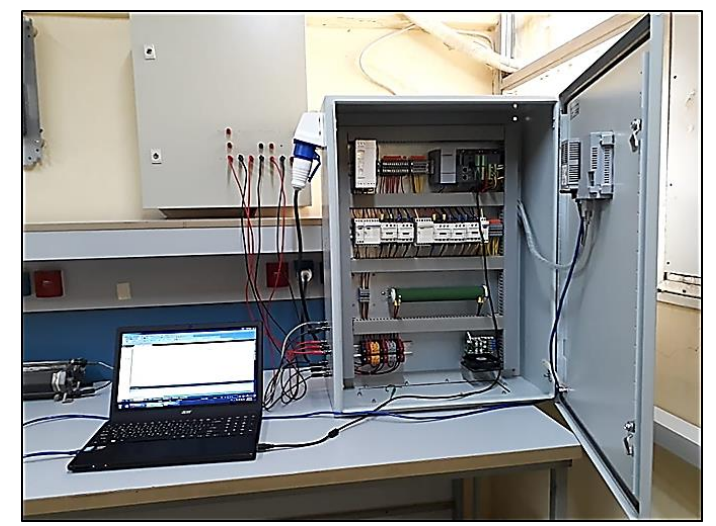

Fig. 2 The Proposed Platform.

\section{A. PLC program}

The PLC program consists of three parts, the first one is data input from HMI screens such as temperature and irradiation and PV cell/module parameters. The second part is solving mathematical equations of the PV module using numerical solution methods (Newton Raphson method because of its convergence speed) for calculation current and voltage of the PV cell/module. The third part is plotting curves as the P-I curve by sending the values of the parameters to HMI and using trend graph function to plot.

The PLC program flow chart is shown in Fig.3

\section{B. HMI Interface}

To create a friendly interfacing environment between the platform users and the driving PLC, six base screens and seven popup window screens have been introduced and configured. These screens are

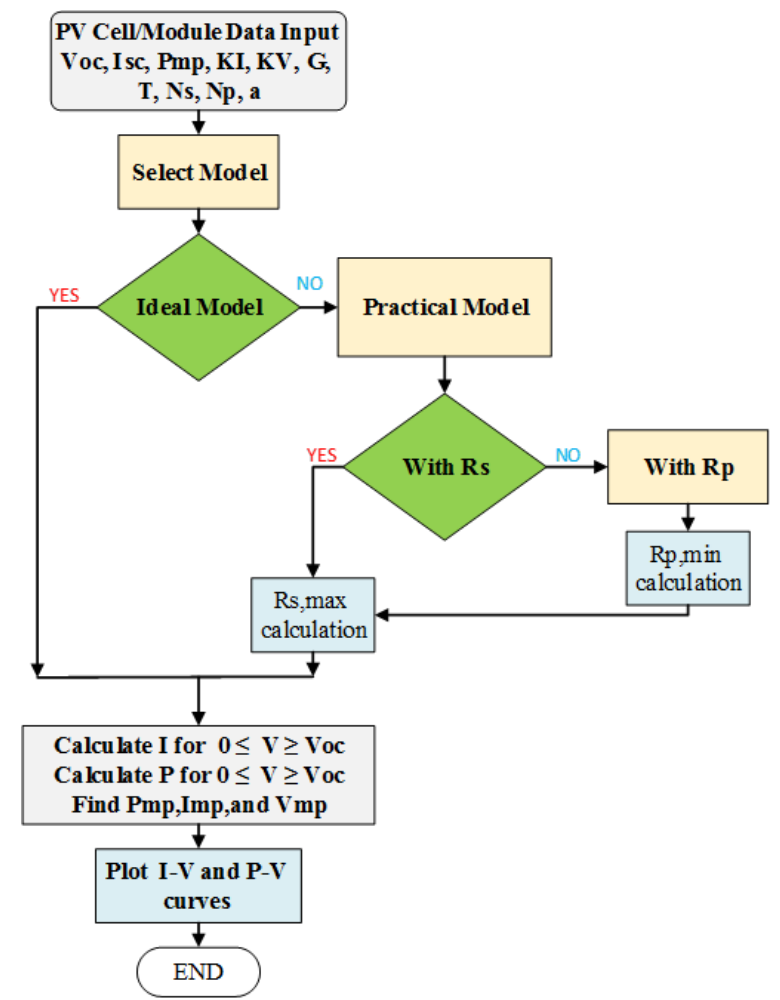

Fig. 3 The PLC program flow chart.

-Navigation Screen (Fig.4): This screen forms the train station, from where the user jumps to the application screen he or she interested with.

-Data Input Screen (Fig.5): This screen is mainly introduced to set the data required for the simulation of the PV cell/module

-PV Unit Simulation Screens (Fig.6): Each screen is used to set and display the various parameters of the PV unit (cell or module) under consideration. With the help of these screens, the user can start the simulation process, plotting P-V and I-V curves for PV cell/module, display different measurements, and allow to change the main parameter.

-PV Curves Plotting Screen (Fig.7): This one has been designed to plot the relationship between the environment conditions (irradiation and temperature) versus PV cell/module short circuit current and open-circuit voltage. This information can be used to get an idea about the PV energy distribution over the day or season.

- Module Diagram Screens (Fig.8): These screens are used to display the used electricalbased model (ideal and practical). A popup screen change switch has been added to the PV simulation screens in the address label. 


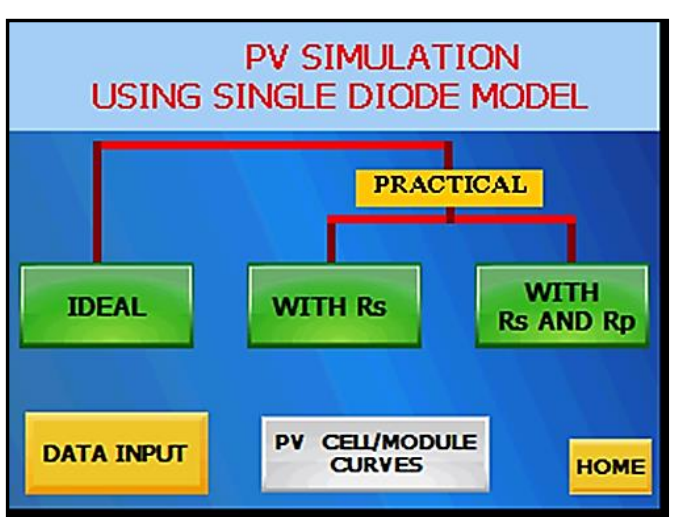

Fig. 4 The Navigation Base Screen.

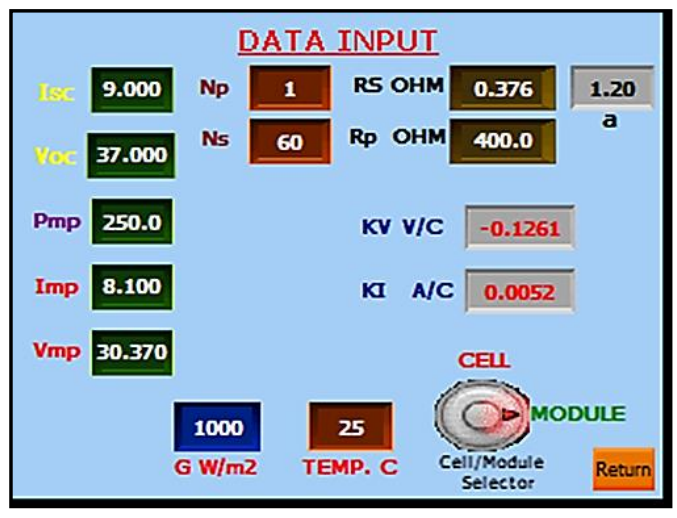

Fig. 5 The Data Input Screen.

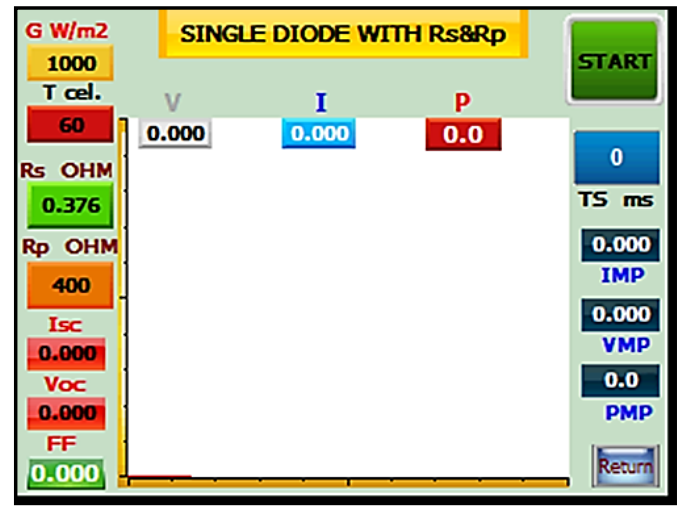

Fig. 6 The Model Type Screen.

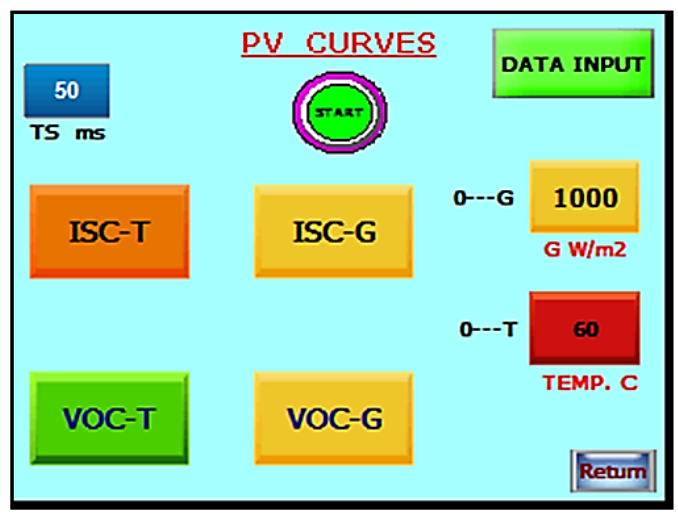

Fig. 7 The PV Curves Screen.

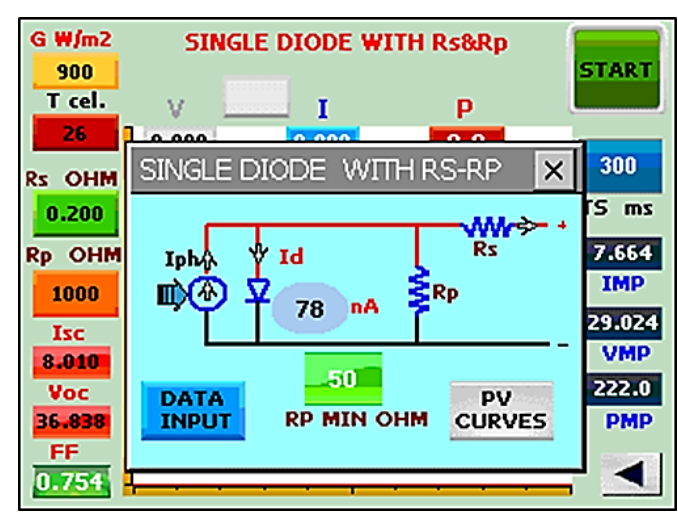

Fig. 8 Model diagram Screen.

\section{CASE STUDY}

To test and validate the applicability of the proposed platform, a number of cases have been discussed. These are model simulation under irradiation changes and simulation under temperature changes. For the comparison between the simulation result and the real one, the PRO SOLAR PS-660250 module has been adopted. The module specifications are listed in Table 1.

TABLE.1 PS-660250 SPECIFICATIONS

\begin{tabular}{|l|c|}
\hline \multicolumn{1}{|c|}{ Parameter } & Value \\
\hline Maximum power $\left(\mathrm{P}_{\mathrm{mp}}\right)$ [Watt] & $250 \mathrm{~W}$ \\
\hline Voltage at MPP $\left(\mathrm{V}_{\mathrm{mp}}\right)[$ Volt] & $30.8 \mathrm{~V}$ \\
\hline Current at MPP $\left(\mathrm{I}_{\mathrm{mp}}\right)[$ Ampere] & $8.14 \mathrm{~A}$ \\
\hline Open-circuit voltage $\left(\mathrm{V}_{\mathrm{oc}}\right)$ [Volt] & $38.2 \mathrm{~V}$ \\
\hline Short-circuit current $\left(\mathrm{I}_{\mathrm{sc}}\right)$ & $9 \mathrm{~A}$ \\
[Ampere] & $+3 \%$ \\
\hline Maximum power tolerance & -0.33 \\
\hline Temperature coefficient of open & $\% /{ }^{\circ} \mathrm{C}$ \\
circuit voltage $\left(\mathrm{K}_{\mathrm{V}}\right)$ & +0.058 \\
\hline Temperature coefficient of short & $\% /{ }^{\circ} \mathrm{C}$ \\
\hline circuit current $\left(\mathrm{K}_{\mathrm{I}}\right)$ &
\end{tabular}

Case1: Model simulation under irradiation changes

It is well known that the irradiation level affects the short circuit current and the open-circuit voltage in addition to the maximum power supplied by the PV module. To simulate the irradiation and discover its effect, the operating temperature has been assumed constant $(25 \mathrm{C})$ and the irradiation level increased from $250 \mathrm{~W} / \mathrm{m} 2$ to $1000 \mathrm{~W} / \mathrm{m} 2$ by step of $250 \mathrm{~W} / \mathrm{m} 2$ using a single diode ideal module. The simulation result is shown in Fig.9. From this figure, one can see the short circuit current, open-circuit voltage, and the PV 
module output power increase as irradiation level increases.

(a)

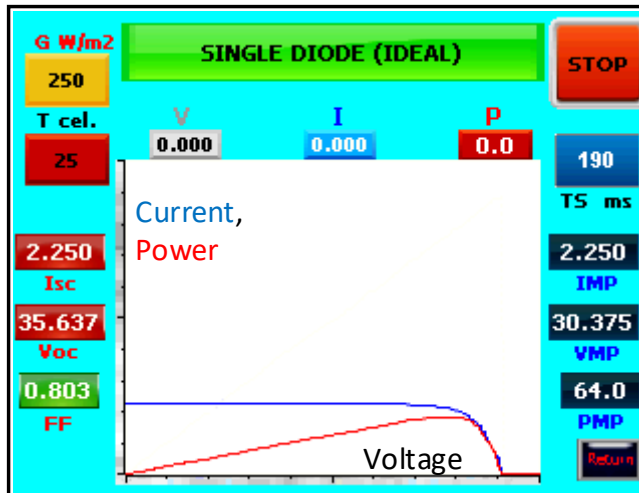

(b)

(c)

(d)
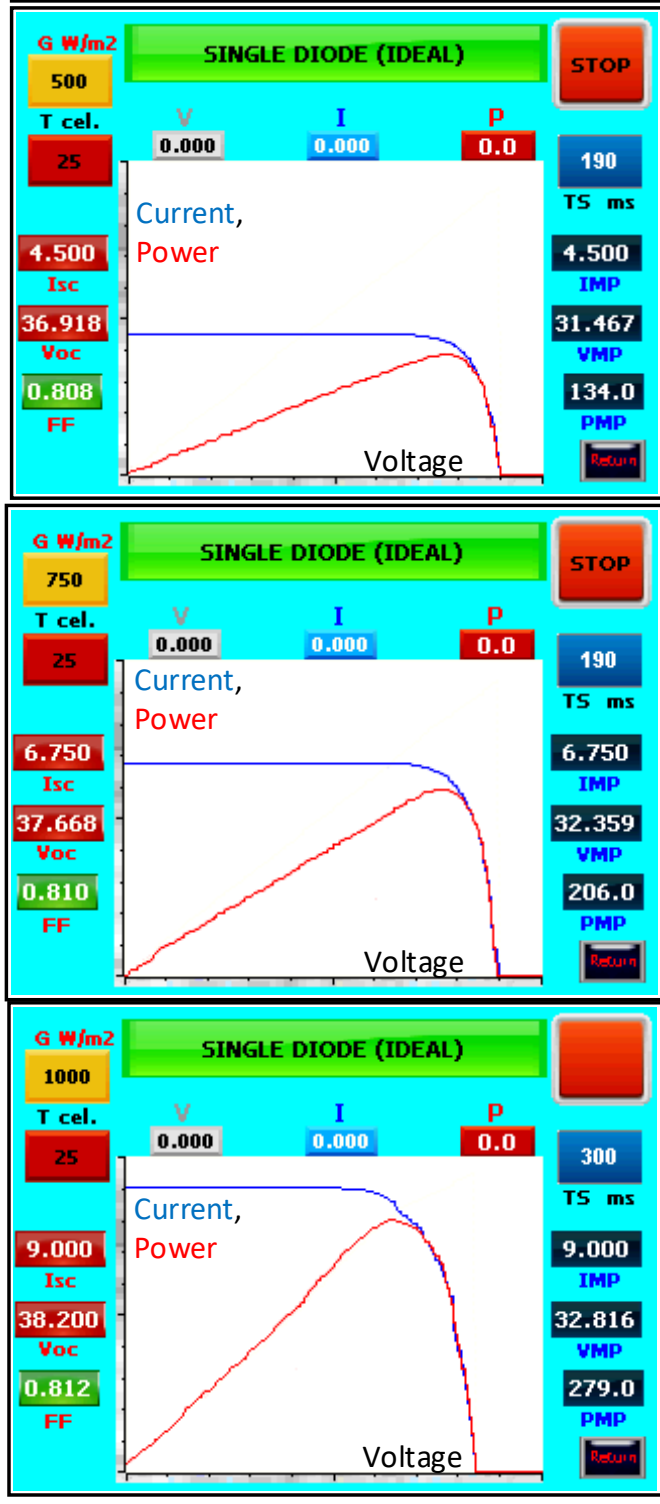

Fig.9 PV module characteristics under irradiation changing a) $\mathrm{G}=250 \mathrm{~W} / \mathrm{m}^{2} \mathrm{~b}$ ) $\mathrm{G}=500 \mathrm{~W} / \mathrm{m}^{2} \mathrm{c}$ ) $\left.\mathrm{G}=750 \mathrm{~W} / \mathrm{m}^{2} \mathrm{~d}\right) \mathrm{G}=1000 \mathrm{~W} / \mathrm{m}^{2}$.

\section{Case2: Model simulation under temperature changes}

The environment temperature is various over the day and the month. In the early morning it is low and at midday reaches its maximum value for that day. The temperature forms one of the parameters that affect the PV module voltage and current. The PV module current increases as the temperature increases and the PV module voltage decreases as the temperature increases. The voltage decreasing is more than the current increasing and this gives power reduction as the temperature increases. For discussing the temperature parameter, the irradiation level has been maintained constant $(1000 \mathrm{~W} / \mathrm{m} 2)$ and the temperature is changed from $15 \mathrm{C}^{\circ}$ to $60 \mathrm{C}^{\circ}$ by step of $15 \mathrm{C}^{\circ}$ using a single diode with Rs\&Rp model as shown in Fig.10.

\section{VALIDATION OF THE PV MODEL}

To discover the degree of closeness between the PV cell/module real-time behavior and it's simulation one three PV modelling cases have been carried out by the PLC. Fig.11a shows the ideal one $(\mathrm{Rs}=0, \mathrm{R} p=\infty)$, Fig. $11 \mathrm{~b}$ show the single diode model with $\mathrm{Rs} \neq 0$ and $\mathrm{R} p=\infty$, and Fig. 11c show the single diode model with $\mathrm{Rs} \neq 0$ and $\mathrm{Rp} \neq$ $\infty$. The simulation for the PV model has been done at STC $\left(25^{\circ} \mathrm{C}\right.$ and $\left.1000 \mathrm{~W} / \mathrm{m} 2\right)$. The comparison between the datasheet of the PRO SOLAR PS660250 module and it's instantiated from the simulation has been carried out and relative error was calculated by the formula

$$
E r \%=(A s-A d) /_{A d}
$$

where As is the simulated value and Ad is the PV value from the datasheet. The comparison and the relative error for a different type of model are illustrated in Table 2. 
(a)

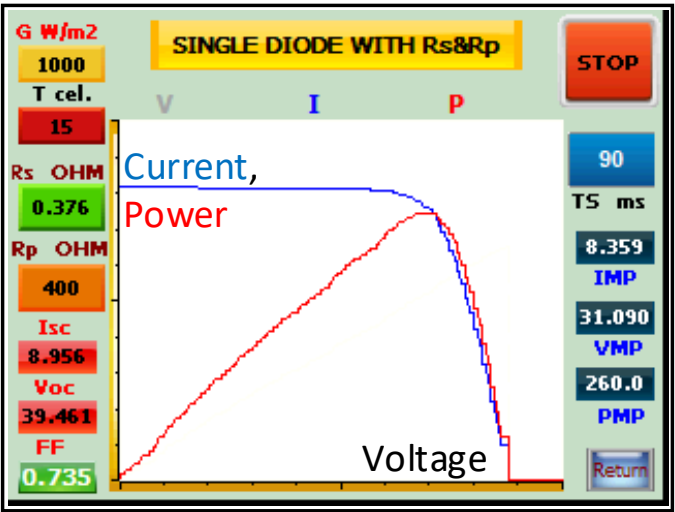

(b)

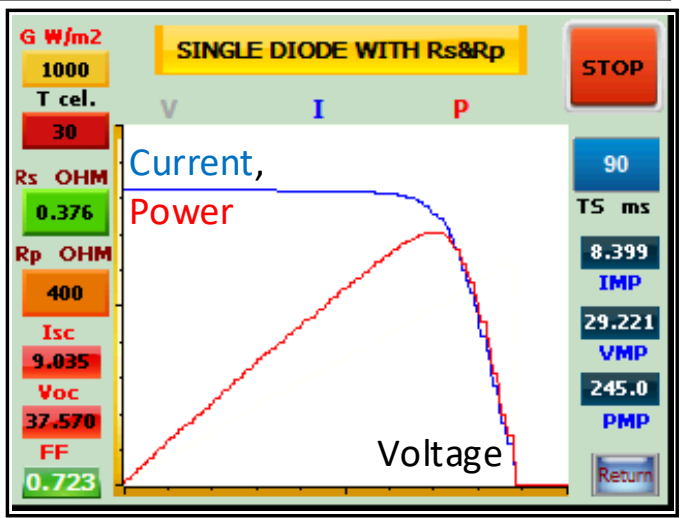

(c)

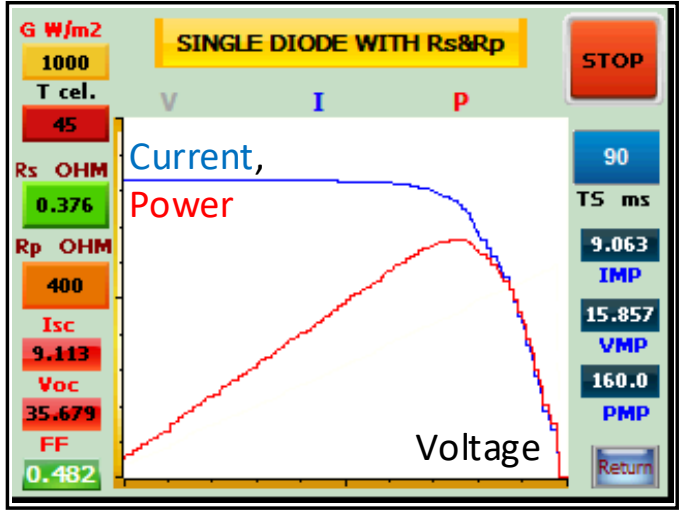

(d)

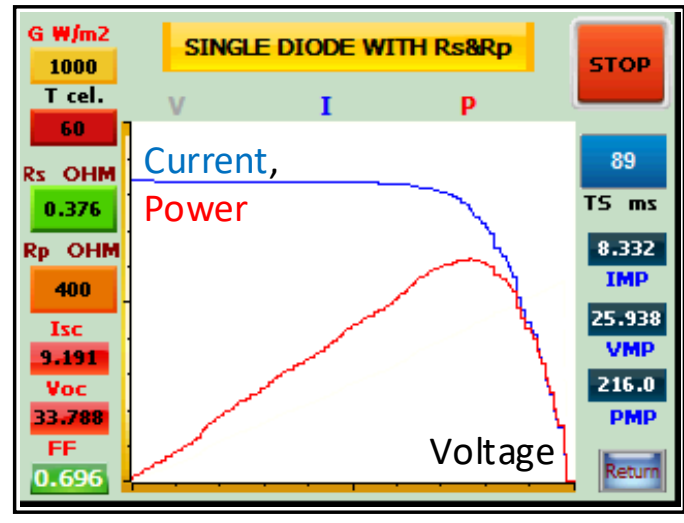

Fig.10 PV module characteristics under temperature changing a) $\mathrm{T}=15 \mathrm{C}^{\circ} \mathrm{b}$ ) $\mathrm{T}=30 \mathrm{C}^{\circ} \mathrm{c}$ ) $\mathrm{T}=45 \mathrm{C}^{\circ}$ d) $\mathrm{T}=60 \mathrm{C}^{\circ}$. (a)

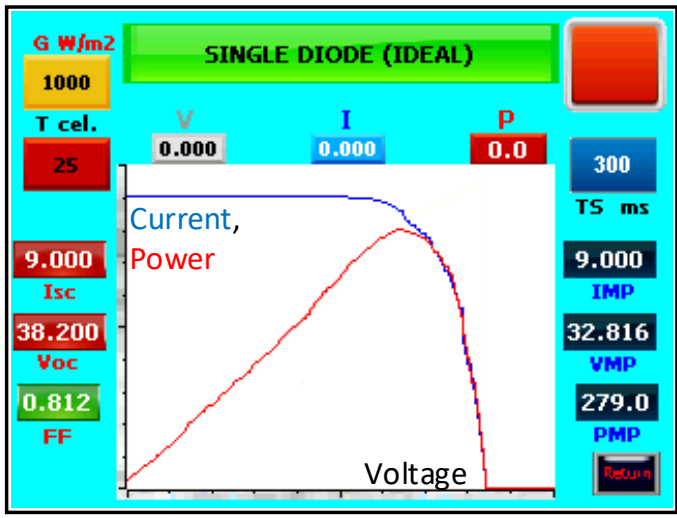

(b)

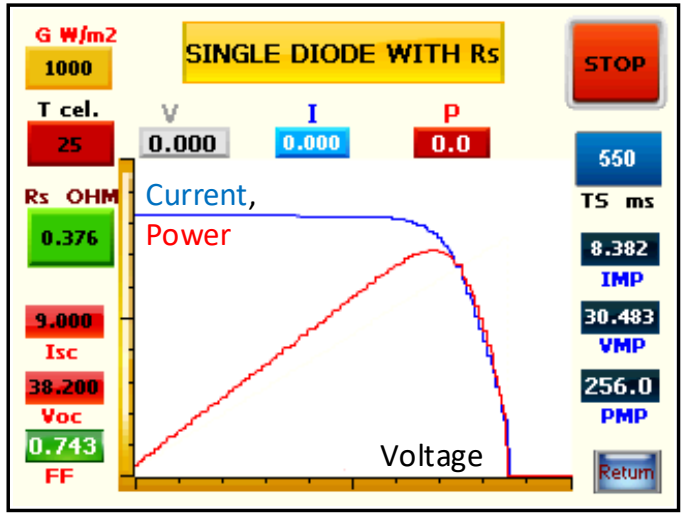

(c)

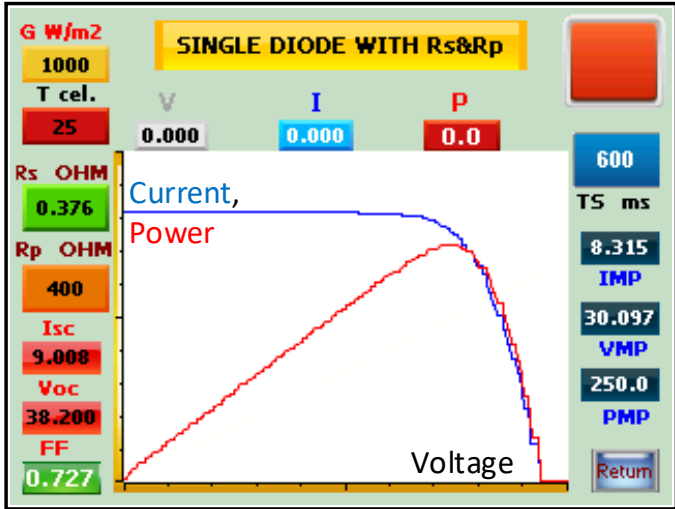

Fig.11 Model simulation result at STC a) Ideal b) With Rs c) With Rs and Rp.

From Table.2, one can see

- At standard test condition, the single diode model types (ideal, with Rs, and with Rs\&Rp) closely simulated the PV module open circuit voltage and short circuit current.

- At STC, the single diode with Rs model and with the Rs\&Rp model gives the best estimation for the PV module maximum power point voltage and current. 
- At STC, the single diode with Rs\&Rp model gives a more accurate prediction to the PV module maximum power.

TABLE. 2

THE SIMULATION RESULT AT STC FOR SINGLE DIODE MODEL

\begin{tabular}{|c|c|c|c|c|}
\hline \multirow{2}{*}{\multicolumn{2}{|c|}{$\begin{array}{l}\text { Model Type } \\
\text { Parameter }\end{array}$}} & \multirow[b]{2}{*}{ Ideal } & \multicolumn{2}{|c|}{ Practical } \\
\hline & & & With Rs & $\begin{array}{l}\text { With Rs } \\
\text { and Rp }\end{array}$ \\
\hline \multirow{3}{*}{ Voc } & Ad & \multicolumn{3}{|c|}{38.2} \\
\hline & As & 38.2 & 38.2 & 38.2 \\
\hline & Er \% & $\overline{0}$ & 0 & 0 \\
\hline \multirow{3}{*}{ Isc } & Ad & \multicolumn{3}{|c|}{9} \\
\hline & As & 9 & 9 & 9 \\
\hline & Er \% & 0 & 0 & 0 \\
\hline \multirow{3}{*}{ Vmp } & Ad & \multicolumn{3}{|c|}{30.8} \\
\hline & As & 32.816 & 30.482 & 30.097 \\
\hline & Er \% & 6.545 & -1.032 & -2.282 \\
\hline \multirow{3}{*}{ Imp } & Ad & \multicolumn{3}{|c|}{8.14} \\
\hline & As & 9 & 8.382 & 8.315 \\
\hline & Er \% & 10.565 & 2.973 & 2.15 \\
\hline \multirow{3}{*}{ Pmp } & Ad & \multicolumn{3}{|c|}{250} \\
\hline & $\overline{\text { As }}$ & 279 & 256 & 250 \\
\hline & Er \% & 11.6 & 2.4 & 0 \\
\hline
\end{tabular}

\section{CONCLUSION}

The obtained simulation result shows that the PLC and HMI can be used efficiently to adopt a PV module simulation utility for the PV's I-V curve, P-V curve, and common maximum power point readings.

The information and discussed simulation and real results state that the proposed work can be adopted as a teaching and testing platform for PV panels.

\section{REFERENCES}

[1] V. J. Chin, Z. Salam, and K. Ishaque, "Cell modelling and model parameters estimation techniques for photovoltaic simulator application: A review," Applied Energy, vol. 154, pp. 500-519, 2015.

[2] B. Nusillard and M. Olmi, "A contribution to the knowledge of the genus Bocchus Ashmead, 1893, with revised keys to the European species (Hymenoptera:
Dryinidae)," Entomologist's Gazette, vol. 59, no. 3, pp. 199-208, 2008.

[3] A. Bellini, S. Bifaretti, V. Iacovone, and C. Cornaro, "Simplified model of a photovoltaic module," 2009 Applied Electronics International Confernce AE 2009, no. October, pp. 47-52, 2009.

[4] M. G. Villalva, J. R. Gazoli, and E. Ruppert Filho, "Modeling and circuitbased simulation of photovoltaic arrays," 2009 Brazilian Power Electronics Conference COBEP2009, no. 4, pp. 12441254, 2009.

[5] J. Park, H. Kim, Y. Cho, and C. Shin, "Simple Modeling and Simulation of Photovoltaic Panels Using Matlab/Simulink," vol. 73, no. Fgcn, pp. 147-155, 2014.

[6] H. Yatimi and E. H. Aroudam, "A Detailed Study and Modeling of Photovoltaic Module under Real Climatic Conditions," International Journal of Electronics and Electrical Engineering, vol. 3, no. 3, pp. 171-176, 2014.

[7] M. Diaw, M. L. Ndiaye, M. Sambou, I. Ngom, and A. Mbaye, "Solar Module Modeling, Simulation And Validation Under Matlab / Simulink," Int. Journal of Engineering Research Application, vol. 6, no. 9, pp. 26-31, 2016.

[8] IEEE Power Electronics Society., Sociedade Brasileira de Eletrônica de Potência., and Institute of Electrical and Electronics Engineers., "COBEP 2009: Bonito, MS, Brazil : September 27 to October 1st, 2009 : [10th] 2009 Brazilian Power Electronics Conference," pp. 12441254, 2009.

[9] J. Jordan and C. Lampkin, "Solar cell array," US Patent 4,243,432, vol. I, no. October 1976, 1981.

[10] S. Pukhrem, "a Photovoltaic Panel Model in Matlab / Simulink," no. October, pp. 20-23, 2013.

[11] J. Bikaneria, S. Prakash Joshi, A. Joshi, A. Service Manager, and K. trucking, "Modeling and Simulation of PV Cell using One-diode model," International Journal of Scientific Research 
Publications, vol. 3, no. 10, pp. 2250-

3153, 2013.

[12] N. N. B. Ulapane, C. H. Dhanapala, S. M.

Wickramasinghe, S. G. Abeyratne, N.

Rathnayake, and P. J. Binduhewa,

"Extraction of parameters for simulating photovoltaic panels," 2011 6th

International Conference on Industrial and

Information Systems ICIIS 2011 - Conf.

Proc., pp. 539-544, 2011. 